\title{
Studies on Genetic Variability, Correlation and Path Analysis for Yield and Yield Related Traits in Greengram [Vigna radiata (L.) Wilczek]
}

\author{
C.K. Divya Ramakrishnan ${ }^{1 *}$, D.L. Savithramma ${ }^{2}$ and A. Vijayabharathi ${ }^{2}$ \\ ${ }^{1}$ Department of Biotechnology, Karpagam University, Coimbatore-641021, Tamil Nadu, India \\ ${ }^{2}$ Department of Genetics and Plant Breeding, University of Agricultural Sciences, \\ Bangalore - 560065, Karnataka, India \\ *Corresponding author
}

\begin{tabular}{|l|}
\hline K e y w o r d s \\
Greengram, \\
$\begin{array}{l}\text { Variability parameters, } \\
\text { Correlation and Path } \\
\text { analysis }\end{array}$ \\
\hline Article Info \\
\hline $\begin{array}{l}\text { Accepted: } \\
\text { 24 February } 2018 \\
\text { Available Online: } \\
\text { 10 March 2018 }\end{array}$ \\
\hline
\end{tabular}

\section{A B S T R A C T}

Genetic variability, heritability, genetic advance of yield attributing characters and their association among them on yield are paramount importance for crop improvement. Correlation and path analysis are important biometrical tools for getting information regarding inter-relationship among various traits used in selection programme. In the present study, twelve yield and yield related parameters have been studied in 374 diverse genotypes of greengram. The genotypes differed significantly for all characters under study except for plant height, number of branches per plant and test weight. Number of clusters per plant, number of pods per plant and number of seeds per pod showed high GCV and PCV values. Heritability estimates in broad sense and genetic advance were high for all the characters except for test weight indicating that estimates reveals the heritable portion of variability. Association analysis indicated that, seed yield per plant showed significant positive correlation with pod yield per plant followed by number of pods per plant, number of clusters per plant and threshing percentage. Among the characters studied pod yield per plant had very high positive direct effect followed by high positive direct effect of number of pods per plant, threshing percentage and number of clusters per plant on seed yield per plant. So, more emphasis should be given to these characters in indirect selection for seed yield improvement in greengram.

\section{Introduction}

Greengram [Vigna radiata (L.) Wilczek] is one of the most important edible food legumes of south and Southeast Asia.

It is third most important pulse crop of India (Rishi, 2009). It is grown mainly in Madhya Pradesh, Maharashtra, Uttar Pradesh, Andhra Pradesh, Karnataka and Rajasthan. Recently domestic consumption of greengram has increased because of the rising popularity in Indian ethnic foods and perceived health benefits (Datta et al., 2012).

The protein is comparatively rich in lysine, an amino acid that is deficient in cereal grains. Greengram seeds are rich in minerals like calcium, iron, magnesium, phosphorus and potassium and vitamins like ascorbic acid, thiamine, riboflavin, niacin, pantothenic acid and vitamin A (Tang et al., 2014). 
Yield is the principal factor for determining improvement of a crop. The most important objective in any crop improvement programme is to increase the seed yield through development of high yielding varieties with disease resistance. A survey of genetic variability such as phenotypic coefficient of variation (PCV), genotypic coefficient of variation (GCV), heritability and genetic advance are absolutely necessary to start an efficient breeding programme. Correlation study indicates the degree of interdependence of important plant characters which forms an important tool in selection of an appropriate genotype. Most of the plant breeding programmes are aimed at augmentation of yield, which is an intricate character dependent on many other component characters which are further related among them. Thus, rendering the correlation study is incompetent. Determination of correlation and path coefficient between yield and yield criteria is important for the selection of favourable plant types for effective plant breeding programmes. Hence, path analysis was done to determine the amount of direct and indirect effect of the causal components on the effective component. Considering these points, the present study was designed to screen the greengram germplasm accessions, to study available genetic variability, heritability, genetic advance, correlation and path analysis for yield and yield related traits which will help in isolating promising lines for hybridization programme and to explore high yield potential and quality traits.

\section{Materials and Methods}

The investigation was carried out to know the genetic variability parameters of 374 greengram germplasm accessions for yield and yield related characters. All the field experiments were conducted in University of Agricultural Sciences, GKVK, Bangalore. All 374 Indian greengram accessions were screened under field conditions by adopting an augmented design II (Federer, 1956). The experimental material obtained from University of Agricultural Sciences, Bangalore, Tamil Nadu Agricultural University, Coimbatore and National Bureau of Plant Genetic Resources (NBPGR), New Delhi. The test entries were planted during mid-July 2010 and harvested during the last week of September 2010. Each test accessions was planted in a single row sub-plot of $2 \mathrm{~m}$ length in an augmented design II with row to row and plant to plant spacing of $30 \mathrm{~cm}$ and $10 \mathrm{~cm}$, respectively. All the recommended package of practices was followed. Standard statistical procedure was used for the analysis of variance, genotypic and phenotypic coefficients of variation (Burton, 1952) and heritability (Hanson et al., 1956). The genotypic and phenotypic correlation coefficients were computed using genotypic and phenotypic variances and covariance. The path coefficient analysis was done according to the method suggested by Dewey and Lu (1959).

\section{Results and Discussion}

Analysis of variance (ANOVA) was carried out for 12 yield and yield related traits in 374 greengram germplasm accessions to test the significant differences among the genotypes under study (Table 1). The analysis of variance revealed significant difference among the genotypes, indicating the presence of genetic variability for almost all the traits studied except for plant height, number of branches per plant and test weight.

\section{Genetic variability studies}

An assessment of heritable and non-heritable components from the total variability is indispensable in adopting suitable breeding procedure. Presence of narrow gap between phenotypic coefficient of variation $(\mathrm{PCV})$ and 
genotypic coefficient of variation (GCV) for all the characters under study suggested that expression of these traits have low environmental influence. The magnitude of range for quantitative as well as qualitative characters was wide, indicating the possibilities of exploiting the available variability for further genetic improvement programmes. One way to achieve this is to explore the largely untapped reservoir of allelic diversity that remains hidden within existing population of germplasm. Range, mean, PCV, GCV, heritability and genetic advance as per cent of mean (GAM) for 12 characters were studied and presented in Table 1.

The higher estimates of GCV and PCV value were observed for plant height. For days to $50 \%$ flowering, low GCV and moderate PCV value was recorded. Estimates of GCV were found to be moderate for number of branches per plant with high PCV. High GCV and PCV values were recorded for number of clusters per plant, number of pods per plant and number of seeds per pod. For days to maturity, pod length number of seeds per pod, threshing percentage, test weight and seed yield per plant, moderate GCV and PCV values were suggesting that these characters are under the influence of additive gene action. These results are in consonance with Borah and Hazarika (1995) in greengram. PCV and GCV were high for plant height, number of clusters per plant, number of pods per plant and pod yield per plant. So, these traits offer scope for direct selection. These findings are in confirmation with Khairnar et al., (2003), Nasser Ahmed and Lavanya (2005) and Mallikarjuna Rao et al., (2006). However, in the present investigation, plant height, days to $50 \%$ flowering, pod length, number of seeds per pod, plant height, number of branches per plant and days to maturity were moderate values of GCV and PCV. The correspondence between values of GCV and PCV indicates the limited influence of environment. Similar results have been reported by Ranga Rao et al., (2005), Ritu et al., (2005) and Mallikarjuna Rao et al., (2006).

Heritability values coupled with genetic advance as per cent of mean (GAM) would be more reliable and useful in formulating selection procedure (Johnson et al., 1955). In the present study, heritability estimates in broad sense and GAM were high for all the characters except for test weight indicating that estimates reveals the heritable portion of variability present in most of characters. Hence, selection for these characters will be rewarding as they were least influenced by environment. Similar results were reported in greengram by Khairnar et al., (2003) Naseer Ahmed and Lavanya (2005) and Mallikarjuna Rao et al., (2006).

\section{Association analysis}

To know the extent of relationship between yield and its various components, it is important for the plant breeder to select plants which consists of desirable characteristics. Phenotypic correlation coefficient was higher for all the important characters like yield and yield related characters (Table 2). Seed yield per plant showed significant positive correlation with pod yield per plant followed by number of pods per plant, number of clusters per plant and threshing percentage. Number of branches per plant, number of pods per plant, number of seeds per pod, pod length and test weight exhibited positive and significant association with seed yield per plant (Rajan et al., 2000; Makeen et al., 2007; Srivastava and Singh, 2012; Kumar et al., 2013; Narasimhulu et al., 2013; Thippani et al., 2013). Days to 50\% flowering expressed positive significant correlation with days to harvest, pod length, test weight. Days to maturity showed significant positive correlation with pod length and test weight. 
Table.1 Analysis of variance and variability parameters for growth, yield and yield related traits in 374 greengram germplasm accessions

\begin{tabular}{|c|c|c|c|c|c|c|c|c|c|c|c|c|c|}
\hline Source of variation & $d f$ & DFF & DH & PH & NBR & NCL & NPD & PL & NSPD & TW & PY & TH\% & SY \\
\hline Blocks & 21 & 0.61 & 1.37 & 4.90 & 0.23 & 1.07 & 8.40 & 0.16 & 1.00 & 0.34 & 0.90 & 7.26 & 0.42 \\
\hline Genotypes + checks & 375 & $5.48 * *$ & $5.35 *$ & 8.66 & 0.23 & $7.86 * *$ & $69.65 * *$ & $0.86^{* *}$ & $1.68 *$ & $3.64 * *$ & $21.34 * *$ & $86.21 * *$ & $11.20 * *$ \\
\hline Checks & 1 & $20.45 * *$ & $19.1 *$ & $66.03 * *$ & 0.09 & $56.82 * *$ & $202.53 * *$ & $1.24 *$ & 1.11 & $716.0 * *$ & $26.35 * *$ & $30.68 *$ & $108.1 * *$ \\
\hline Genotypes & 373 & $5.43 * *$ & $5.27 *$ & 8.31 & 0.23 & $7.61 * *$ & $69.27 * *$ & $0.86^{* *}$ & $1.68 *$ & 0.07 & $21.22 * *$ & $83.37 * *$ & $10.71 * *$ \\
\hline Checks Vs. Genotypes & 1 & $8.62 * *$ & $21.5 * *$ & $82.36 * *$ & 0.25 & $50.84 * *$ & $78.64 * *$ & $3.13 * *$ & 1.32 & $624.0 * *$ & $60.93 * *$ & $1201.9 * *$ & $92.31 * *$ \\
\hline Error & 21 & 1.07 & 2.54 & 7.55 & 0.38 & 0.96 & 6.26 & 0.18 & 0.78 & 0.47 & 0.92 & 5.46 & 0.41 \\
\hline \multicolumn{14}{|c|}{ Variability parameters } \\
\hline \multirow{2}{*}{\multicolumn{2}{|c|}{ Mean \pm SD }} & 32.76 & 70.03 & 26.42 & 2.81 & 6.45 & 19.49 & 6.64 & 11.20 & 3.19 & 9.73 & 62.48 & 6.19 \\
\hline & & \pm 2.33 & \pm 2.29 & \pm 2.88 & \pm 0.47 & \pm 2.76 & \pm 8.32 & \pm 0.93 & \pm 1.30 & \pm 0.26 & \pm 4.61 & \pm 9.13 & \pm 3.37 \\
\hline \multirow[t]{2}{*}{ Range } & Min. & 29.00 & 67.00 & 19.30 & 1.00 & 2.00 & 6.00 & 3.00 & 5.00 & 2.43 & 1.76 & 26.58 & 1.00 \\
\hline & Max. & 50.00 & 90.00 & 34.00 & 3.00 & 15.00 & 45.00 & 14.80 & 15.00 & 4.25 & 27.69 & 85.83 & 22.63 \\
\hline GCV (\%) & & 10.02 & 13.32 & 26.44 & 19.73 & 30.51 & 40.52 & 11.05 & 12.06 & 80.07 & 75.55 & 10.99 & 13.45 \\
\hline PCV $(\%)$ & & 11.66 & 14.71 & 27.01 & 21.67 & 32.22 & 43.93 & 12.56 & 13.99 & 82.65 & 77.93 & 12.35 & 15.66 \\
\hline$h_{(\mathrm{bs})}^{2}(\%)$ & & 71.40 & 63.05 & 73.22 & 70.11 & 90.68 & 59.83 & 80.18 & 70.42 & 72.16 & 90.68 & 60.16 & 91.24 \\
\hline GAM (\%) & & 20.07 & 28.35 & 65.80 & 69.96 & 89.58 & 66.72 & 78.13 & 47.96 & 82.23 & 79.94 & 31.27 & 95.54 \\
\hline
\end{tabular}

* Significance at $P=0.05 * *$ Significance at $P=0.01$ 
Table.2 Phenotypic correlation coefficients for growth, yield and yield related characters on seed yield per plant in 374 greengram germplasm accessions

\begin{tabular}{|c|c|c|c|c|c|c|c|c|c|c|c|}
\hline Trait Name & DH & PH & NBR & NCL & NPD & PL & NSPD & TW & PY & TH \% & SY \\
\hline DFF & $0.144 * *$ & 0.074 & -0.023 & 0.049 & 0.015 & $0.278 * *$ & 0.098 & $0.140 * *$ & 0.049 & 0.073 & 0.070 \\
\hline$\overline{\mathrm{DH}}$ & 1 & -0.010 & 0.004 & -0.09 & $-0.104^{*}$ & $0.235 * *$ & 0.073 & $0.180 * *$ & -0.055 & 0.005 & -0.048 \\
\hline $\mathbf{P H}$ & & 1 & $-0.134 * *$ & -0.020 & 0.004 & $-0.103^{*}$ & -0.087 & -0.097 & -0.014 & 0.026 & -0.002 \\
\hline NBR & & & 1 & 0.047 & 0.068 & -0.061 & 0.046 & $0.144 *$ & 0.095 & -0.075 & 0.077 \\
\hline NCL & & & & 1 & 0.527 & -0.086 & -0.067 & -0.030 & $0.471 * *$ & $0.240 * *$ & $0.479 * *$ \\
\hline NPD & & & & & 1 & -0.099 & -0.090 & 0.065 & $0.923 * *$ & $0.266 * *$ & $0.892 * *$ \\
\hline PL & & & & & & 1 & $0.655^{* *}$ & $0.228 * *$ & -0.032 & $0.124 *$ & 0.010 \\
\hline NSPD & & & & & & & 1 & $0.138 * *$ & -0.056 & 0.087 & -0.012 \\
\hline TW & & & & & & & & 1 & 0.094 & 0.033 & 0.096 \\
\hline TH\% & & & & & & & & & & 1 & $0.477 * *$ \\
\hline
\end{tabular}

\begin{tabular}{|l|l|l|l|l|l|l|l|l|}
\hline DFF & - & Days to $50 \%$ flowering & NPD & - & Number of pods per plant & TH $\%$ & - & Threshing percentage \\
\hline DH & - & Days to harvest & PL & - & Pod length $(\mathrm{cm})$ & SY & - & Seed yield per plant $(\mathrm{g})$ \\
\hline PH & - & Plant height $(\mathrm{cm})$ & NSPD & - & Number of seeds per pod & & \\
\hline NBR & - & Number of branches & TW & - & Test weight $(\mathrm{g})$ & \\
\hline NCL & - & Number of clusters per plant & PY & - & Pod yield per plant $(\mathrm{g})$ & & \\
\hline
\end{tabular}


Table.3 Path coefficient analysis for growth, yield and yield related characters on seed yield per plant in 374 greengram germplasm accessions

\begin{tabular}{|c|c|c|c|c|c|c|c|c|c|c|c|c|}
\hline Trait Name & DFF & DH & PH & NBR & NCL & NPD & PL & NSPD & TW & PY & TH\% & $r$ \\
\hline DFF & -0.184 & 0.200 & -0.165 & -0.177 & 0.056 & -0.114 & 0.223 & 0.049 & 0.219 & 0.067 & -0.104 & 0.070 \\
\hline$\overline{\mathrm{DH}}$ & 0.023 & -0.185 & -0.194 & -0.198 & 0.016 & 0.206 & 0.217 & 0.019 & 0.225 & 0.011 & -0.188 & -0.048 \\
\hline$\overline{\mathbf{P H}}$ & -0.019 & -0.024 & 0.097 & -0.211 & 0.135 & -0.049 & -0.222 & 0.137 & -0.003 & 0.084 & 0.073 & -0.002 \\
\hline NBR & 0.036 & -0.027 & 0.025 & -0.109 & 0.018 & 0.029 & -0.056 & -0.115 & 0.218 & 0.061 & -0.003 & 0.077 \\
\hline NCL & 0.023 & 0.037 & -0.198 & -0.195 & 0.313 & 0.029 & 0.014 & 0.025 & 0.011 & 0.208 & 0.212 & $0.479 * *$ \\
\hline NPD & -0.028 & -0.198 & 0.113 & 0.128 & -0.198 & 0.411 & 0.175 & 0.163 & -0.198 & 0.236 & 0.288 & $0.892 * *$ \\
\hline $\mathbf{P L}$ & -0.169 & -0.181 & -0.198 & -0.190 & 0.017 & 0.020 & 0.033 & 0.412 & 0.214 & -0.169 & 0.221 & 0.010 \\
\hline NSPD & -0.176 & -0.169 & 0.015 & -0.109 & 0.013 & 0.022 & 0.019 & 0.101 & 0.217 & 0.021 & 0.034 & -0.012 \\
\hline TW & 0.034 & -0.059 & -0.039 & -0.057 & -0.109 & 0.077 & 0.101 & 0.089 & 0.054 & 0.046 & -0.041 & 0.096 \\
\hline PY & -0.185 & -0.155 & -0.179 & 0.083 & 0.102 & 0.050 & -0.185 & 0.061 & -0.195 & 1.290 & 0.277 & $0.964 * *$ \\
\hline TH\% & -0.031 & -0.057 & 0.042 & -0.055 & 0.025 & 0.029 & -0.055 & 0.037 & 0.066 & 0.143 & 0.333 & $0.477 * *$ \\
\hline
\end{tabular}

\begin{tabular}{|c|c|c|c|c|c|c|c|c|}
\hline DFF & - & Days to $50 \%$ flowering & NCL & - & Number of clusters per plant & TW & - & Test weight (g) \\
\hline DH & - & Days to harvest & NPD & - & Number of pods per plant & PY & - & Pod yield per plant (g) \\
\hline PH & - & Plant height $(\mathrm{cm})$ & PL & - & Pod length $(\mathrm{cm})$ & TH\% & - & Threshing percentage \\
\hline NBR & - & Number of branches & NSPD & - & Number of seeds per pod & & & \\
\hline
\end{tabular}


Days to maturity showed significant negative correlation with number of pods per plant. Bhattacharya and Vijayalaxmi (2005) reported $50 \%$ flowering exhibited significant positive association with days to harvest, pod length and test weight. Thus, selection of genotypes which is attaining days to $50 \%$ flowering early will result in early maturity. Plant height expressed significant negative correlation with number of branches per plant and pod length. Number of branches per plant showed positive significant correlation with test weight per plant. Number of clusters per plant revealed positive significant association with pod yield per plant, threshing percentage and seed yield per plant. If the observed correlation is due to multiple effects of same gene, the selection for one character will improve another character simultaneously. Hence, correlations among traits influence effectiveness of selection. These results are in agreement with the findings of Rajan et al., (2000), Ahmad et al., (2013) and Narasimhulu et al., (2013). Number of pods per plant recorded positive significant association with pod yield per plant, pod length, test weight and threshing percentage. Similar results of pods per plant exhibited positive and significant correlation with pod yield per plant, threshing percentage and seed yield per plant were also observed by Makeen et al., (2007), Kumar et al., (2010), Srivastava and Singh (2012) and Ahmad et al., (2013).

Pod yield per plant expressed positive significant association with pod length and test weight. Pod length reported positively significant correlation with number of seeds per pod and test weight. Among the characters, pod yield per plant showed highest positive significant correlation with seed yield per plant, number of pods per plant with pod yield per plant, number of pods per plant with seed yield per plant and pod length with number of seeds per pod. These results are in agreement with the results of Venkateshwarlu
(2001), Haritha and Reddy Shekar (2002), Motiar and Hussain (2003), Anuradha and Suryakumari (2005) and Mallikarjuna Rao et al., (2006). Number of seeds per pod had positive significant association with test weight. Test weight exhibited non-significant positive or negative association with all the characters except number of pods per plant which had positive significant relationship.

\section{Path coefficient analysis}

To know the direct and indirect effects of seed yield and yield related traits, correlation coefficient was further partitioned into direct and indirect effects through path coefficient analysis at phenotypic level by considering seed yield per plant as a dependent character. Yield is the sum total of the several component characters which directly or indirectly contributed to it. The information derived from the correlation studies indicated only mutual association among the characters. Whereas, path coefficient analysis helps in understanding the magnitude of direct and indirect contribution of each character on the dependent character like seed yield per plant.

Among the characters studied pod yield per plant had very high positive direct effect followed by high positive direct effect of number of pods per plant, threshing percentage and number of clusters per plant on seed yield per plant. Number of clusters per plant expressed moderate level of positive indirect effect on seed yield per plant through pod yield per plant and threshing percentage, whereas number of pods per plant exhibited moderate positive indirect influence on seed yield per plant through pod yield per plant and threshing percentage (Table 3 ). Pod yield recorded moderate positive influence on seed yield per plant through threshing percentage. This result is in agreement with the results obtained by Venkateshwarlu (2001b), Haritha and Reddy Shekar (2002), Anuradha and 
Suryakumari (2005) and Mallikarjuna Rao et al., (2006). The present investigation indicated that there is a wide range of genetic variability in greengram germplasm. There is large scope of simultaneous improvement in seed yield through selection. However, it would be worthwhile to study more available germplasm over years and locations to identify more diverse accessions as well as to confirm the importance of the traits identified as predictors of yield. High heritability estimates coupled with moderate to high genetic advance were observed for seed yield per plant, number of pods per plant and number of seeds per pod suggests that genotypic variation in the present material for these traits was due to high additive gene effect and direct selection for these traits may be rewarding. In conclusion, significant positive association and high direct effect with number of pods per plant followed by number of clusters per plant, pod yield and threshing percentage on seed yield per plant. Strong association of these traits revealed that the selection based on these traits would ultimately improve the pod yield. Hence, the above mentioned characters should be given topmost priority while formulating a selection strategy for improvement of yield in greengram.

\section{References}

Ahmad, A., Razvi, S.M., Rather, M.A., Gulzafar, M.A. Dar and Ganie, S.A. 2013. Association and inter-relationship among yield and yield contributing characters and screening against Cercospora leaf spot in mung bean (Vigna radiata L.). Scient. Res. Essays, 8(41): 2008-2014.

Anuradha, T. and Suryakumari, S. 2005. Genetic parameters, correlation and path analysis in greengram. Andhra Agric. J., 52: 279-281.
Bhattacharya, A. and Vijayalaxmi. 2005. Genetic diversity in greengram: phenological, physiological and yield forming traits. Legume Res., 28: 1-6.

Borah, H.K. and Hazarika, M.H. 1996. Genetic variability and character association in some exotic collection of green gram. Madras Agric. J., 82(4): 268-271.

Burton, G.W. and De Vane G.M. 1953. Estimating heritability in tall Fescue (Festuca arundinaceae) from replicated clonal material. Agron. J., 45: 478-481.

Datta, S., Gangwar, S., Shiv Kumar, Gupta, S., Rai, R., Kaashyap, M., Singh, P., Chaturvedi, S.K., Singh, B.B. and Nadarajan, N. 2012. Genetic diversity in selected Indian greengram [Vigna radiata (L.)Wilczek] cultivars using RAPD markers. American J. Pl. Sci., 3: 1085-1091.

Dewey, D.R. and Lu, K.H. 1959. A correlation and path coefficient analysis of components of crested wheat grass seed production. Agron. J., 51(9): 515518.

Federer, W.T. $1956 . \quad$ Augmented designs. Hawaiian Planters Record. 55: 191-208.

Hanson, C.H., Robinson, H.F. and Comstock, R.E. 1956. Biometrical studies on yield in segregating populations of Korean Lespedeza. Agron. J., 48: 286-329.

Haritha, S. and Reddy Shekhar M. 2002. Correlation and path coefficient analysis in greengram [Vigna radiata (L.) Wilczek]. Legume Res., 25: 180-183.

Johnson, R.W., Robinson, H.F. and Comstock, R.E. 1955. Estimates of genetic and environment variability in soybean. Agron. J., 47: 314-318.

Khairnar, M.N., Patil J.V., Deshmukh, R.B. and Kute, N.S. 2003. Genetic variability in greengram. Legume Res., 26: 69-70.

Kumar, K., Prasad, Y., Mishra, S.B., Pandey, S.S. and Kumar, R. 2013. Study on 
genetic variability, correlation and path analysis with grain yield and yield attributing traits in greengram [Vigna radiata (L.) Wilczek]. The Bioscan, 8(4): 1551-1555.

Kumar, N.V., Roopa Lavanya, G., Singh, S.K. and Pandey, P. 2010. Genetic association and path coefficient analysis in greengram [Vigna radiata (L.) Wilczek]. AAB Bioflux, 2(3): 251-257.

Makeen, K., Abrahim, G., Jan, A. and Singh, A.K. 2012. Genetic variability and correlations studies on yield and its components in greengram (Vigna radiata (L.) Wilczek.). J. Agron., 6(1): 216-218.

Mallikarjuna Rao, C., Koteswara Rao, Y. and Mohan Reddy. 2006. Genetic variability and path analysis in greengram. Legume Res., 29: 216-218.

Motiar, Md. Rehman and Iqbal Hussain, A.S.M. 2003. Genetic variability, correlation and path analysis in greengram. Asian J. Plant Sci., 2: 12091211.

Narasimhulu, R., Naidu, N.V., Shanthi Priya M., Govardhan, G., Reddy, D.M., Reddy, K.H.P. and Raja Rajeswari, V. 2013. Genetic divergence studies in greengram (Vigna radiata L. Wilczek). Int. J. Appl. Biol. Pharmaceutical Tech., 4(4): 277-280.

Naseer Ahmed and Lavanya, G.R. 2005. Genetic variability studies in genotypes of greengram [Vigna radiata (L.) Wilczek]. Andhra Agric. J., 52: 577579.
Rajan, R.E.B., Wilson, D. and Kumar, V. 2000. Correlation and path analysis in $\mathrm{F}_{2}$ segregating generation of greengram (Vigna radiata L. Wilczek). Madras Agric. J., 87: 10-12.

Ranga Rao, G., Y. Koteshwara Rao and Mallikarjuna Rao, C. 2005. Genetic divergence in greengram [Vigna radiata (L.)Wilczek]. Andhra Agric. J., 52: 350353.

Rishi, N. 2009. Significant plant virus diseases in India and a glimpse of modern disease management technology. J. General Pl. Pathol., 75: 1-18.

Ritu, R., Saxena, P.K., Singh and Ravi, R.S. 2005. Multivariate analysis in greengram. Indian J. Pulses Res., 18: 26-27.

Srivastava, R.L. and Singh, G. 2012. Genetic variability, correlation and path analysis in greengram (Vigna radiata (L.) Wilczek). Indian J. Life Sci., 2(1): 6165.

Tang, D., Dong, Y., Guo, N., Li, L. and Ren, H. 2014. Metabolomics analysis of the polyphenols in germinating mung beans (Vigna radiata) seeds and sprouts. $J$. Sci. Food Agric., 94(8): 1639-1647.

Thippani, S., Eswari, K.B. and Brahmeswar Rao, M.V. 2013. Character association between seed yield and its components in greengram (Vigna radiata (L.) Wilczek). Inter. J. Appl. Sci. Pharm. Tech., 4(4): 295-297.

Venkateshwarlu, O. 2001. Correlation and path analysis in greengram. Legume Res., 24: 115-117.

\section{How to cite this article:}

Divya Ramakrishnan, C.K., D.L. Savithramma and Vijayabharathi, A. 2018. Studies on Genetic Variability, Correlation and Path Analysis for Yield and Yield Related Traits in Greengram [Vigna radiata (L.) Wilczek]. Int.J.Curr.Microbiol.App.Sci. 7(03): 2753-2761. doi: https://doi.org/10.20546/ijcmas.2018.703.318 